\title{
DEVELOPING DEROKO'S THEORIES: LOOKING FOR THE “INCUNABULA" OF BYZANTINE HOUSING
}

\section{Serena Acciai}

Politecnico of Milan

University of Florence

serena.acciai@polimi.it|serena.acciai@unifi.it

\section{A B S T R A C T}

Looking at the Byzantine palaces that have survived through centuries until today, such as the Palace of the Porphyrogenitus (Palace of Belisarius) in Istanbul, Aleksandar Deroko has underlined the essential distinction between two fundamental genres of Byzantine houses: monumental palaces made of stone and bricks and everyday houses made with a wooden structure.

For centuries, the ordinary Byzantine house was considered as a "Turkish type". Deroko maintained that this classification was erroneous, as the Ottomans actually inherited "the Byzantine house" when they conquered the vast territory of the Byzantine Empire. The Byzantine house was adopted by the Ottomans and the people under their domination, and over the centuries it spread over a broad geographical area - from Anatolia to North Africa and to the Balkans. Unsurprisingly, it did not reflect a single heritage; instead, it mirrored the various cultures that fell under its rule.

Based on Deroko's theories, one could consider locations such as Mount Athos, Ioannina, Prizren, Ohrid, Elena and even certain villages of Arbëreshë (Italo-Albanian) communities of South Italy as the "incunabula (the first examples, the origins) of Byzantine housing”. Probably, thanks to their morphological characteristics and geographical isolation, some elements of this building type are still visible in these locations, even though they have been integrated into the local housing cultures. These buildings give subtle glimpses of the everyday Byzantine house. 


\section{INTRODUCTION}

This study reevaluates the impact of the Byzantine house culture in a panorama of vernacular architecture in the former Eastern Roman Empire territories. The overarching goal is to demonstrate how this housing culture still lives and continues to evolve. I will do so by using Deroko's theories to analyze the incunabula of the Byzantine house type that has survived to present day.

The analysis is based on selected case studies, and shows how constitutive elements of the Byzantine houses became an integral part of many historical buildings in the Mediterranean. The methodological approach used in this study is an innovative mix of typological and historical analysis. The typological analysis ${ }^{1}$ focuses on the formative elements of a building, whereas the historical analysis helps to contextualize them.

\section{The Byzantine House - Background}

Numerous examples of the Byzantine house can be found in most Mediterranean countries, including Turkey, Greece, Italy, Spain, and Morocco. It is not a coincidence that where the traces of the Byzantine elements are deeply rooted in the morphological layout of the city one can also find a marked presence of Ottoman civil architecture. Given the dimensions of the geographical area it has affected and the duration of its existence, the Byzantine house cannot and should not be considered as a single type of housing. In fact, over time, multiple typological variations have occurred to the Byzantine house type, which was later incorporated in the Ottoman house type.

Beginning with Italy, the heart of Roman art and architecture, we find that in the territory of this peninsula the Byzantine past can be traced in "fragments" in civil architecture. The effects of Byzantine rule on the cities of Italy, although scattered from north to south, have different vicissitudes: from an architectural point of view it is possible to observe how some typical elements of the Byzantine housing culture remain in some of these places. These are not evident traces, but architectural features that have entered very deeply into the language of the built heritage of the various Italian regions.

The historic center of Ferrara, for example, still preserves the original Byzantine castrum, or urban system. In the Byzantine center of Ferrara one can see the covered passageways characteristic of the Byzantine urban fabric called "vasternia"2 (from Latin basterna). 


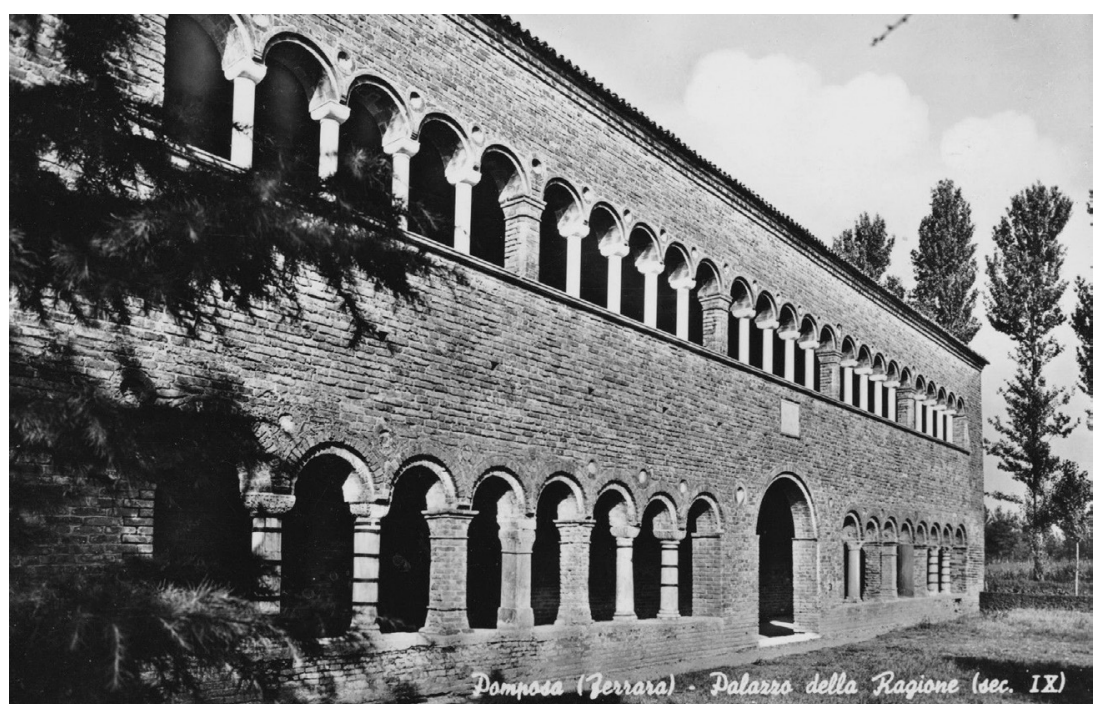

Fig. 1. Palazzo della Ragione in Pomposa, $4^{\text {th }}$ century. (Source: postcard, author's collection.)

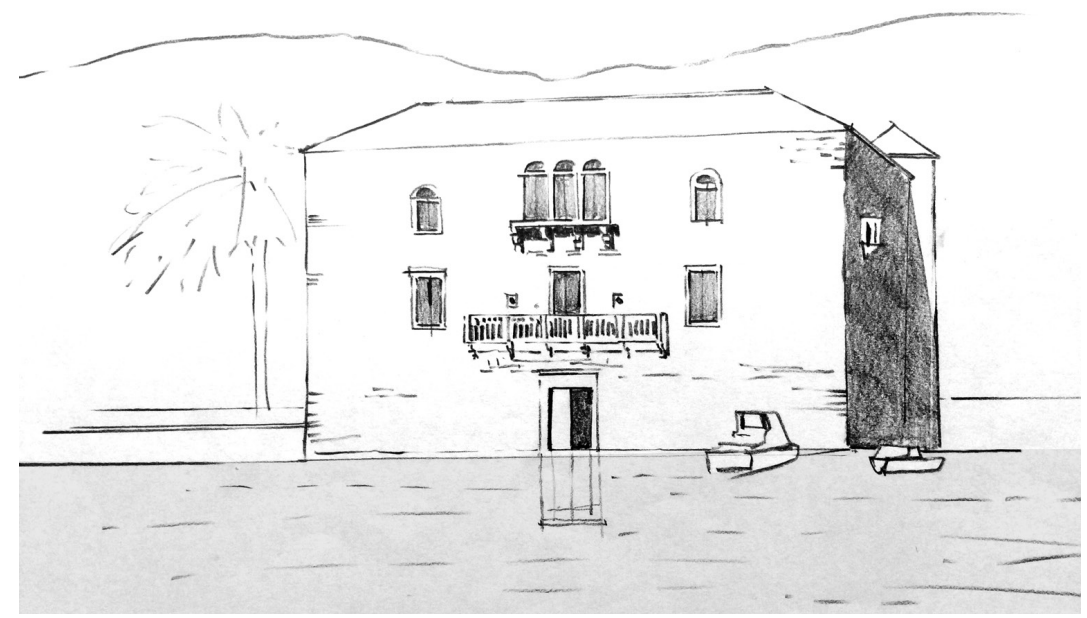

Fig. 2. Kaštel Lukšić, late $15^{\text {th }}$ century (Croatia). (Source: Author's drawing.)

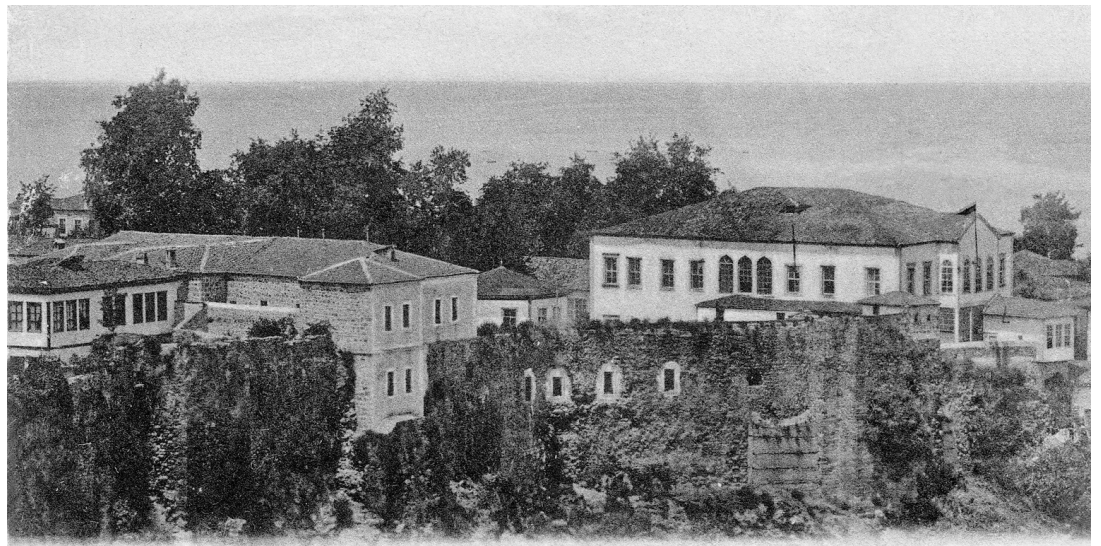

Souvenir de Zrébizonde.

Vue exterieure du palais et des prisons.

Fig. 3. The Comneni's Palace in Trabzon, $13^{\text {th }}-14^{\text {th }}$ century. (Source: postcard, author's collection.) 
Another significant example is undoubtedly the Palazzo della Ragione in the Pomposa Abbey complex, also in the Ferrarese area close to the Po delta. The façade's cadence closely resembles the façades of the Fondaco dei Turchi in Venice and the many openings of all the Byzantines palaces along the shores of the Mediterranean: from the Byzantine-style façade of Kaštel Lukšić ${ }^{3}$ to Diocletian's Palace in Split, the Palace of Galerius in Thessaloniki, to the Palace of Boukoleon on the Marmara Sea, to the Comneni's Palace in Trabzon, on the Black Sea. In the ancient village of Tivoli, outside Rome, one can observe a house ${ }^{4}$ that is reminiscent of houses of Mystras in Greece (the most representative example of the surviving Byzantine housing) in the treatment of its façade and molding creating a unique slab. And, again one can find a house profile with first, second and third levels protruding onto the street in Venice. The ledges are made of wood and the protrusion grows with the house levels. A case in point is the Ramo Barzizza ${ }^{5}$, a small court on the back of the ancient Contarini's Palace on the Canal Grande.

In the Balkans,the situation is somewhat more complicated: in fact there the combination of Byzantine and Ottoman elements is different in each region. And different from Italy, the presence of Byzantine elements are much more evident in the historical civil architectural panorama.

\section{DEROKO'S VIEW ON THE BYZANTINE HOUSE TYPE}

Deroko's (1894-1988) approach to this delicate subject appears to be led by compositional thoughts that have crossed over the historical "ties" in order to analyze the problem from an unconventional point of view. His approach to the Byzantine house type is without any doubt lively and innovative. One can consider his work as a cornerstone in the understanding of the relationship between the Byzantine and the Ottoman civil architecture.

The great Deroko's intuition ${ }^{6}$ was to refer his theories to places that - based on their morphological characters and geographical isolation - have maintained some Byzantine elements in their domestic architecture over time.

According to the Serbian architect, the ordinary house type that for centuries was erroneously considered only as a "Turkish type" was inherited by the Ottomans when they conquered the vast territory of the Byzantine Empire. Deroko, looking at the Byzantine palaces that have survived for centuries to this day, such as the Palace of the Porphyrogenitus, underlined the essential distinction between two fundamental genres of Byzantine houses: monumental palaces made of stone and bricks, and everyday houses made of wood. 


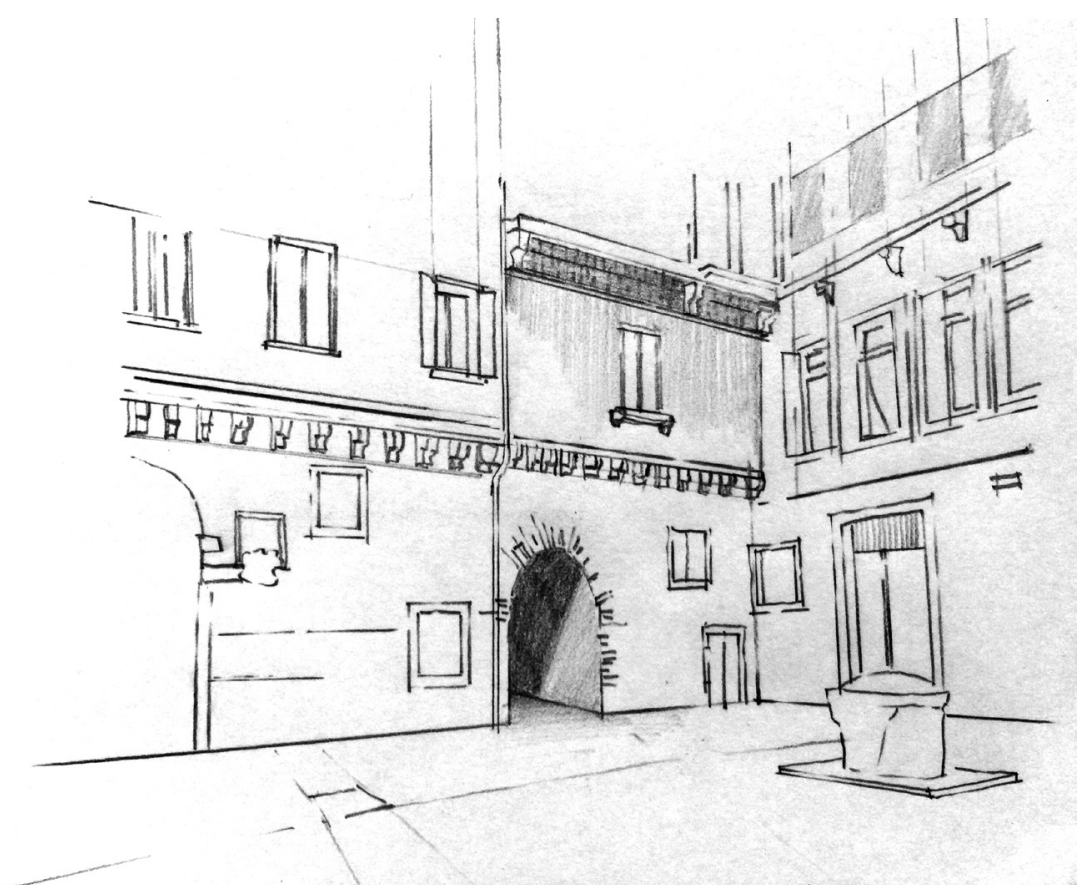

Fig. 4. Ramo Barzizza in Venice, $12^{\text {th }}-13^{\text {th }}$ century. (Source: Author's drawing.)

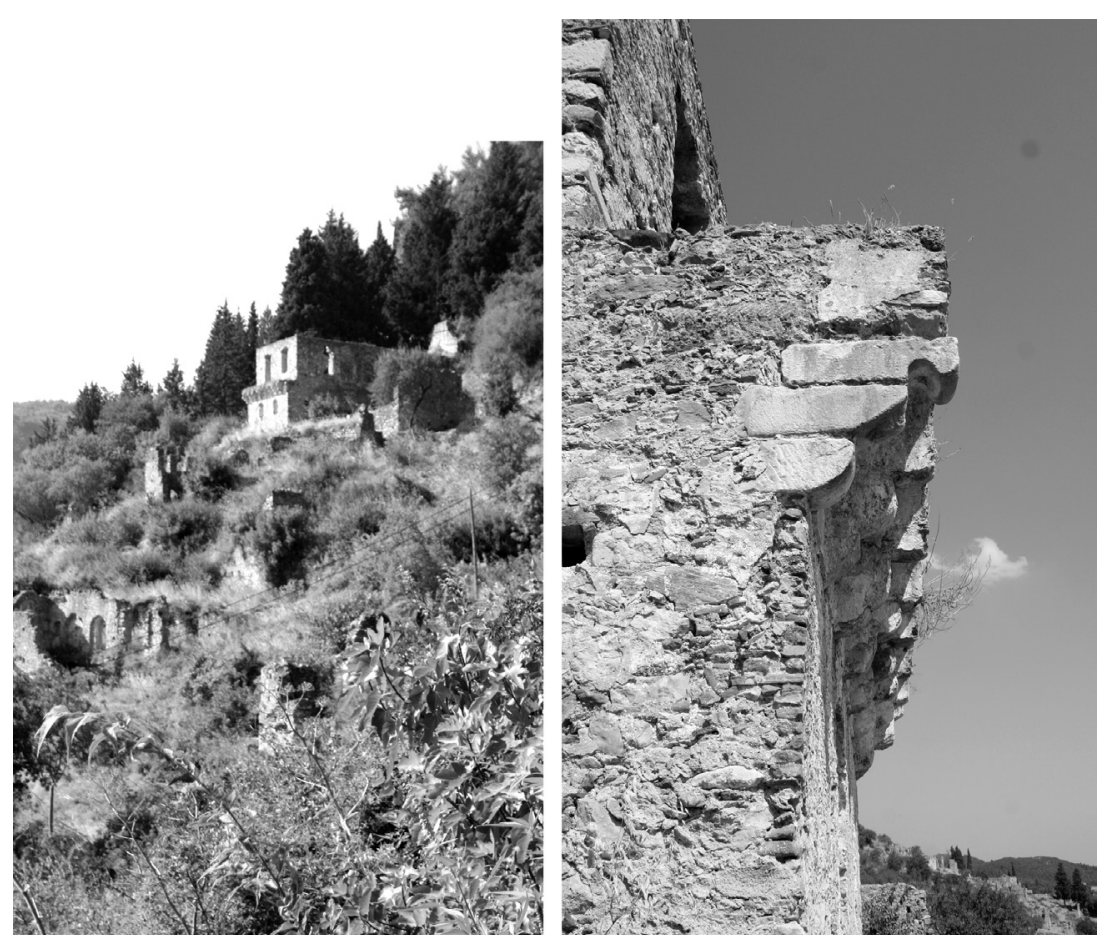

Fig. 5. Houses in Mystras. (Source: photographs by Francesco Collotti.) 
However, he did not consider the important example of Mystras ${ }^{7}$, a locality in Greece that was abandoned during the nineteenth century and has been untouched ever since. There one can see the Byzantine house type as it was. A fortified town and a former municipality in Laconia, this ancient city is situated on Mount Taygetos, near ancient Sparta. The city served as the capital of the Byzantine Despotate of the Morea in the fourteenth and fifteenth centuries, experiencing a period of prosperity and cultural flowering.

Looking at Mystras's vestiges, in particular the house of Laskarius ${ }^{8}$, it is evident that both the Byzantine houses and the palaces were made of stones and bricks, and the plan was formed by a single-room space, often organized on two levels.

Deroko instead considered that the Byzantine houses were made of wood, with a ground floor or a stone basement. In fact, he described the Byzantine house as built of wood with filled panels made of clay and straw; according to him this house type was carried on by the Ottomans and by people under their domination, and spread out over a broad geographical area, from Asia Minor to North African coastal cities. Using Mount Athos architecture as an example he highlighted the essential features of the building technique used for Byzantine houses:

The essential feature are walls not in compact and solid masonry, but with wood frame, with a filling made of malleable material including clayey earth. In the Balkans and Asia Minor, the houses also differ somewhat according to the country.

The ground floor is made of walls built of rubble or dry brick, reinforced by horizontal beams. The floor is built like a cage, in wood. The wooden trellised walls are then filled with dry brick, pieces of wooden beams, all coated with clay. These floors often protrude, partially, or sometimes completely (kiosks). Roofs, with very wide awnings and gentle slopes, are covered with hollow tiles.

The interior layout always has a large central space, sort of "hall" around which are arranged the residential rooms. The kitchen, the storerooms and the servants are relegated to the ground floor. ${ }^{9}$

Deroko made the distinction between Byzantine houses and palaces, based on the building material; he claimed that the houses were built of wood, while the palaces were built of stone. He then used this distinction to support his claim that there were no Byzantine houses left, because of the perishability of their building materials. At first glance, this assumption could be correct, but the village of Mystras and the examples of the Byzantine houses in the Fener or Balat districts of Istanbul (as reported by General Leon De Beylé) point to the contrary. 


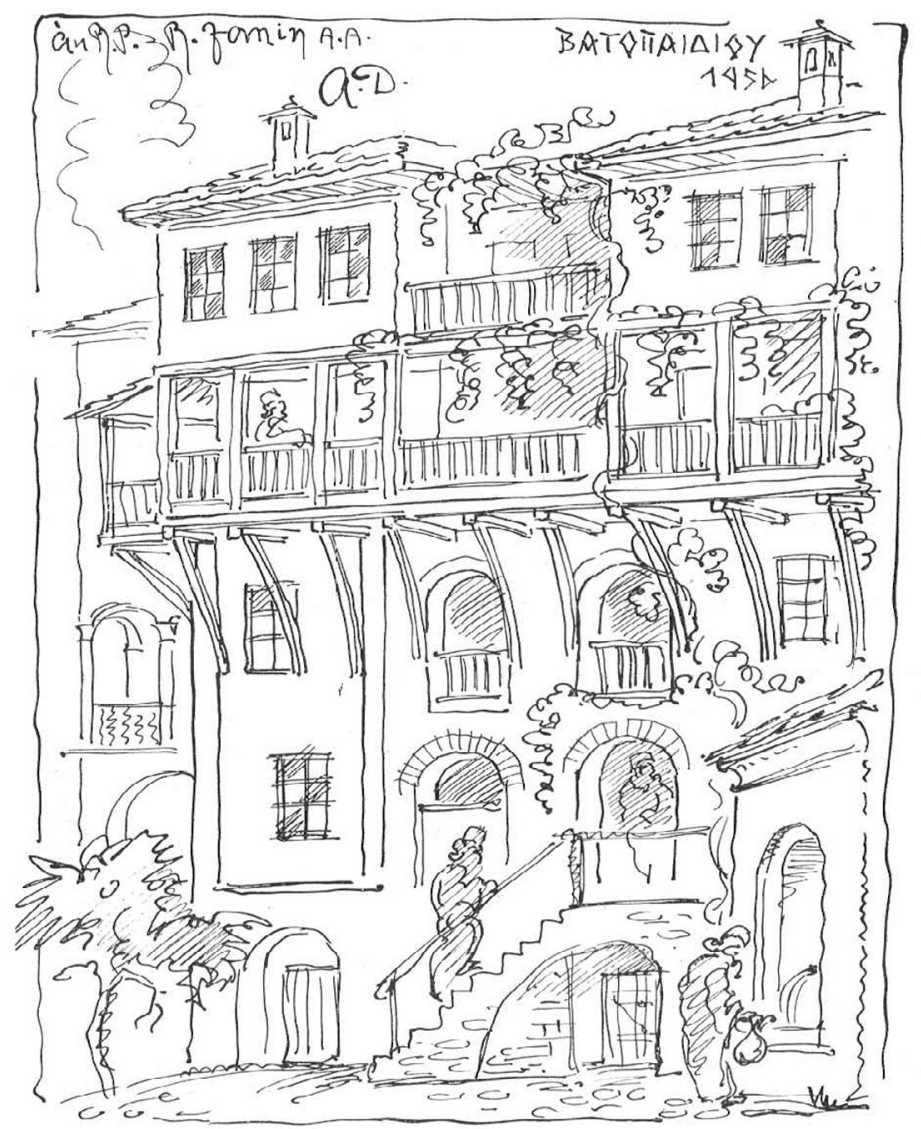

Fig. 6. Friars' houses in Mount Athos. (Source: Deroko Aleksandar. "Deux genres d'architecture dans un monastère," Revue des études byzantines, tome 19, 1961, 388.

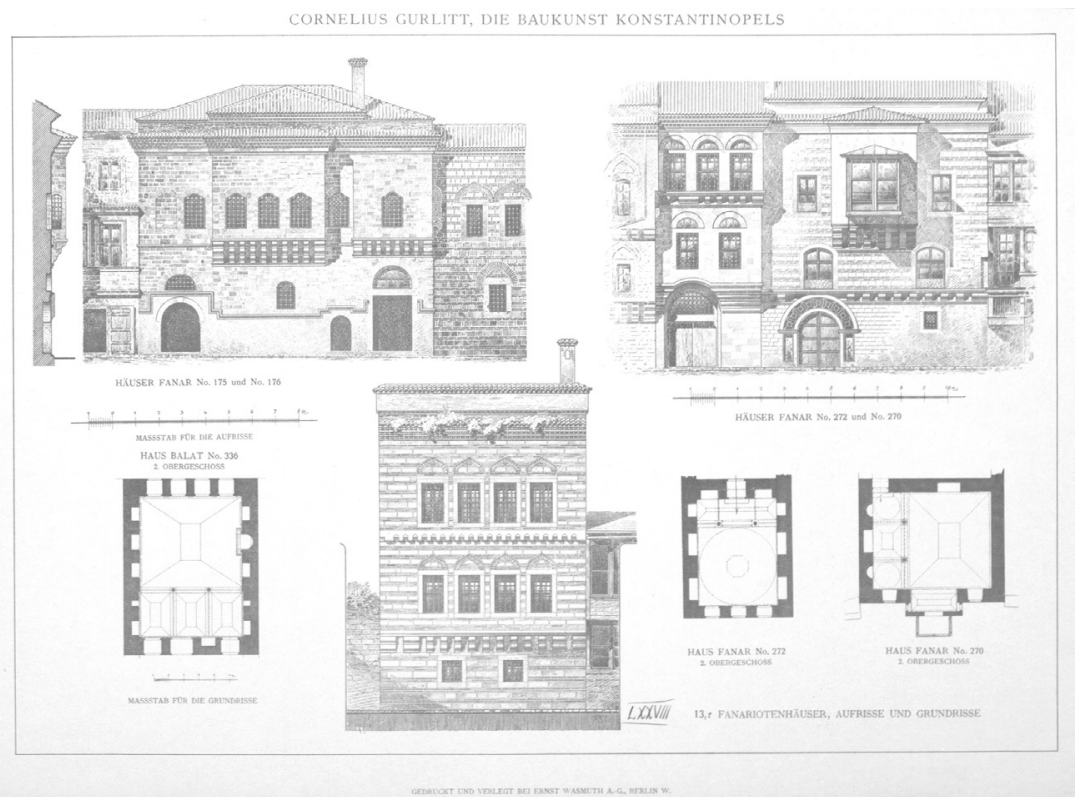

Fig. 7. Houses in the Fener district of Istanbul. (Source: Gurlitt Cornelius. Die Baukunst Konstantinopels. Berlin. Wasmuth,1907.) 


\section{LITERATURE ON THE SUBJECT}

The Byzantine house has been addressed not without difficulty by many scholars, architects and intellectuals. Their efforts, however, inevitably remain weak due to the absence of clear examples of how this building could have been.

General Leon De Beylé's ${ }^{10}$ studies on the subject remain fundamental. They are relevant because of their vastness and the systematic nature of the analysis he carried out. It is necessary to mention the fascinating essay by Swoboda ${ }^{11}$ on the transmigration of Byzantine façades along the shores of the Mediterranean, but also the work of Sergio Bettini on Venice ${ }^{12}$ and Ennio Concina's ${ }^{13}$ studies on the Byzantine city.

Tatiana Kirova ${ }^{14}$, among other scholars, asserted that the study of the Byzantine house type was problematic because of the lack of clear examples left over time. In fact, to find examples of intact Byzantine houses one needs to adopt an evolutive approach considering the scale of essential cross-cultural influences at the time and how widespread this housing type is geographically.

Deroko, as other architects of Modern architecture who worked in the Balkan and Eastern territories, dealt with the legacy of Byzantine architecture: architects such as Branislav Kojić, Nikolaos Moutsopoulos, Sedad Hakkı Eldem and Boris Čipan were interested in documenting the vernacular architecture as an expression of peoples culture and identity. Later they will use this material to reinterpret the tradition in a modern context.

Branislav Kojić (1899-1987) belonged to a generation of French-educated architects. He was a professor at the Faculty of Architecture of the University of Belgrade and a regular member of the Serbian Academy of Sciences and Arts.

In 1940 Kojić led a study of the traditional mansion of Avzi-pacha in Bardovce ${ }^{15}$ near Skopje with his students from the Faculty of Architecture in Belgrade. A young Čipan (1918-2012) was among these students, who was asked by Kojić to cooperate with him in editing his book on "village architecture"16. During his studies, Čipan came into contact with several other professors, such as Deroko, who asked him to make drawings for his book on medieval towns and fortresses in Macedonia ${ }^{17}$. 


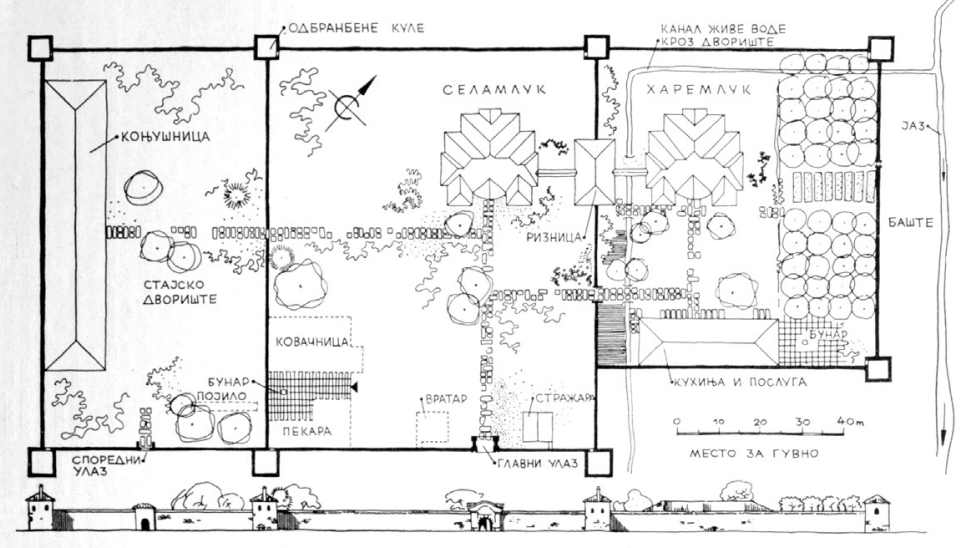

Fig. 8. Avzi-pacha mansion in Bardovce near Skopje: drawings by Boris Čipan. (Source: Kojić Branislav. "L'habitation seigneuriale d'Avzipacha à Bardovce près de Skoplje." In Zbornik zaštite spomenika kulture, no. 4-5, 1954, 22.)

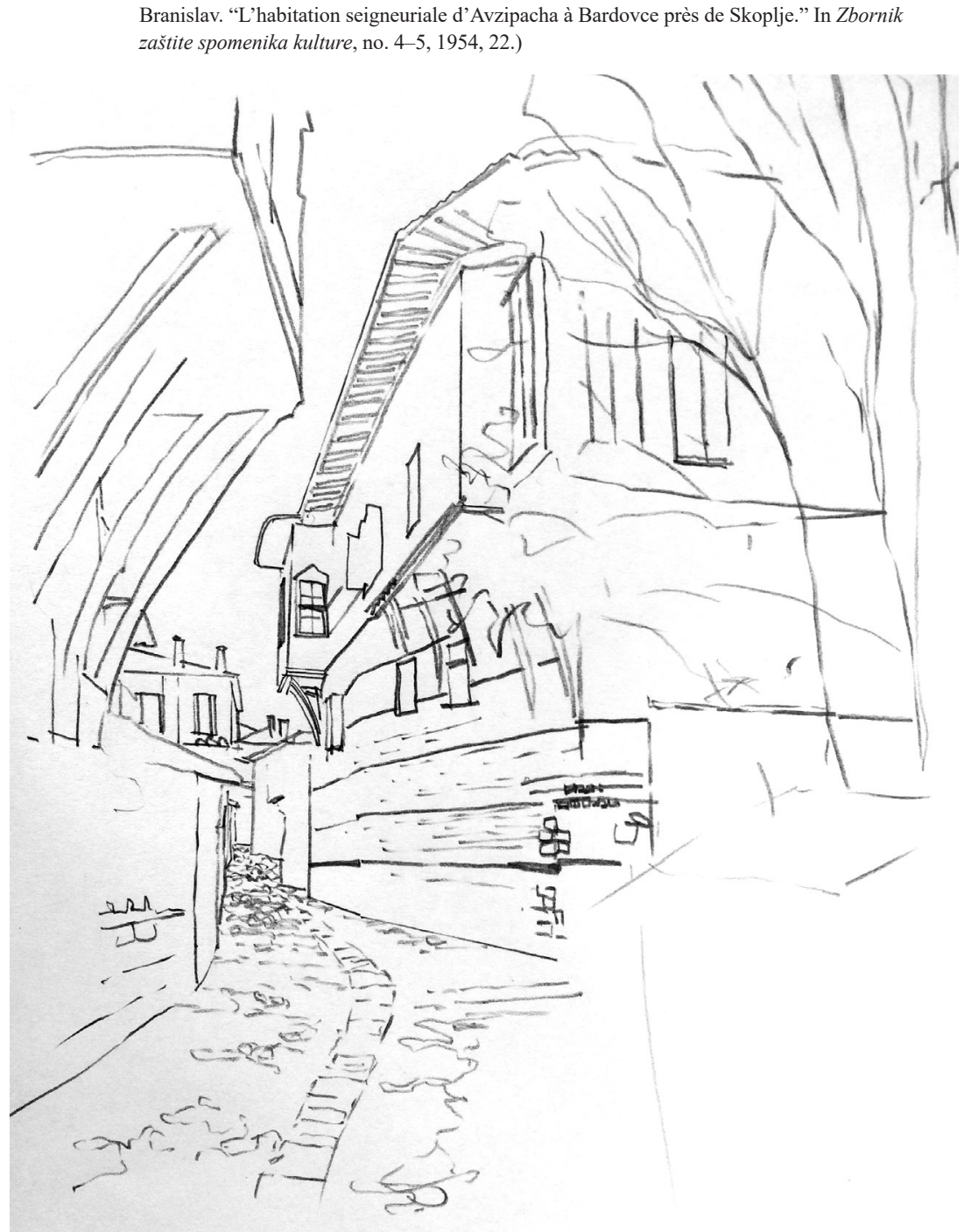

Fig. 9. Typical street in Kastoria. (Source: Author's drawing.) 
Čipan was a Macedonian architect and a prominent figure of Macedonian Modern architecture after the World War II (WWII). He also tried to define the nature of ancient housing architecture of the Balkan regions: in fact, in his paper entitled L'ancienne architecture d'immeuble à Ohrid ${ }^{18}$ Čipan argued how the Ottomans clearly adopted the Byzantine housing tradition and continued to modify it to meet their needs.

Eldem (1908-1988) ${ }^{19}$ was the most preeminent representative of Modern architecture in Turkey and professor at the Mimar Sinan Fine Arts University in Istanbul. He dedicated a whole chapter of his trilogy on the Turkish Ottoman house $^{20}$ to the Byzantine Influence. He was very skeptical in respect to the theories that traced the evolution of the Byzantine house to the Ottoman house. In fact, in his first book on the Turkish house Eldem wrote:

It should not be forgotten that the term "Byzantine House" itself, in reality, is not well defined. The Byzantine Empire lasted for more than 1,000 years. In some places the period was shorter, but not less than 300 years (Syria, Serbia and Bulgaria). The Byzantine House, originating from the Roman House, occupied a period until the end of the Middle Ages and, just like the Ottoman Empire, the houses were dispersed in places greatly separated from each other in different life styles and weather conditions. Under these circumstances, just by saying "The Byzantine House" would not offer a concrete subject. Which period? Which region? Should be the subject that needs explanation in the essence of time and space. [...]

Information about the Old Empire is practically non-existent. [...]

The last palace left from the Byzantine period is the Palace of Porphyrogenitus of the twelfth century in Istanbul. The earlier ones are either in ruins or buried beneath the ground. The palaces in Trabzon, Izmit, Iznik, and Edirne are in such a state of destruction that is not possible to identify them. In Rumeli, there are some castle ruins from the period before the conquest. These are monuments left over from the Serbian, Byzantine and Athenian dukedoms. Apart from Mystras, the rest of them consist of only the tower and the curtain wall. Even if we assume that these buildings were constructed under the Byzantine influence, their ruins confirm nothing. ${ }^{21}$

Beyond these skeptical words Eldem also wrote that the Ottomans superimposed their "way of life" on the housing examples they found during their conquest of territories of the Byzantine Empire. 
Moutsopoulos $^{22}$ (1927), one of the most important intellectuals studying traditional Greek architecture and professor at the Aristotle University of Thessaloniki, wrote the following about the traditional settlements in Greece:

The ties of the family, the principal social cell, had a patriarchal and austere aspect. The house was the limits of the world of the majority of its inhabitants. Their life, their activity, began and ended in the house. In Greece, we usually meet the house type with a large façade typical of the rural dwellings. Over the time this stretched façade has been added, in the front side, of the portico on the ground floor. Called hayat this space means (in Turkish) - life - and together with the other building annexes - at the ground floor - shapes the house plan in a form similar to the "closed atrium".

The streets of the ancient Macedonian cities and villages were paved with caldirim, or cobblestone. They were very narrow and they became still more so with the multiplication of kiosks, called sahnisins. This characteristic dates back to the Byzantine era when the streets were narrow and the solariums ${ }^{23}$, or sahnisin, were wooden and projected on the streets. ${ }^{24}$

Each of these scholars had a different point of view regarding the prevalence of the various housing cultures: this phenomenon derived from their own cultures and from what they wanted to demonstrate in their studies. However, all of them had a typological approach to this subject. These architects promoted in their respective countries the study of civil architecture as a foundation for the development of modern architecture's awareness of the "preexistences". One can affirm that this kind of approach was mostly tied to the study of the Ottoman house in the Balkan Peninsula: the architects that led these efforts constituted a sort of "net of knowledge" 25 and their collaboration is a wonderful, unexpected example of international activity of their common cultural heritage. In the historiography of architecture, this experience should be deeply studied and divulged like the CIAM's experiences.

The international cooperation between architects had its "golden period" with the Congres Internationaux d'Architecture Moderne 1928-1959 (CIAM). Its foundation marks the determination of modernist architects to promote and polish their theories. When it comes to the vernacular architecture, the collective imagination of architects of the Modern Movement was strongly influenced by the IV CIAM meeting ${ }^{26}$, as well as by the desire to consider the Greek Islands' houses a symbol of primitive architecture, but also heralding a modern language to be pursued. Likewise the cultural heritage of the Byzantine/Ottoman house 
studied by modern architects should be considered as an important field of studies because it will give an overview of modern architects' standing on the vernacular architecture along the Mediterranean Sea.

\section{A TYPOLOGICAL APPROACH TO THE CHARACTERISTICS OF THE BYZANTINE HOUSE}

With a sort of poetic license one can try to develop Deroko's theory of "continuation and persistence" of Byzantine architectural elements in the successive domestic cultures and identify those places where still today some characteristics of the houses evoke the elements forming the Byzantine house type.

In his essay ${ }^{27}$ on monastic architecture, Deroko wrote that he has found wellpreserved examples of this building type in several cities of the Balkans and Anatolia, such as Mount Athos, Ankara, Prizren, Ohrid, Plovdiv, Elena, and some villages of North $\mathrm{Africa}^{28}$. These architectural parts and structures give glimpses of how the everyday Byzantine house appeared.

Looking at the Mount Athos housing architecture, in northeastern Greece, it is possible to observe what Deroko has described as the permanence of the characteristics of the Byzantine house. In fact, the geographical isolation of Mount Athos, and the fact that monastery housing complexes have been rebuilt every time in the same manner, have contributed to the conservation of this site.

Beyond these case studies, the Mediterranean offers a particular little known example of transmigration of the Byzantine culture and identity: this is the story of the Arbëreshë villages in the south of Italy. The Arbëreshë communities are made up of the Albanian minority that settled here in the fifteenth century. They are mostly concentrated in 16 scattered macro areas and over 100 municipalities in Sicily, Calabria, Basilicata, Puglia, Campania, Molise and Abruzzo.

There are several testimonies, documented and still accessible, about the habits and customs of these ancient Albanian minorities, but very little documentation concerning their housing type ${ }^{29}$. Thanks to research based on notarial acts, it has been possible to date the arrival of the first Albanians in Italy around the second half of the fifteenth century following the death of Albania's national hero Giorgio Castriota, also known as Scanderbeg, who fought the Ottoman Turks to a standstill in the early fifteenth century. His descendants, fleeing from the Ottoman dominion, found refuge and hospitality in southern Italy thanks to an old treaty between the condottiero and the King of Naples. 


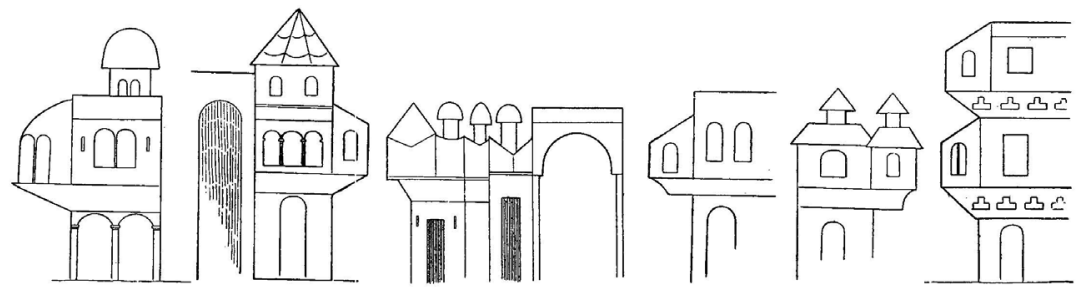

Fig. 10. Byzantine houses profiles. (Source: De Beylié Leon. L'habitation byzantine, recherches sur l'architecture civile des Byzantins et son influence en Europe. Grenoble. Éditeur F. Perrin, 19021903, 191.)

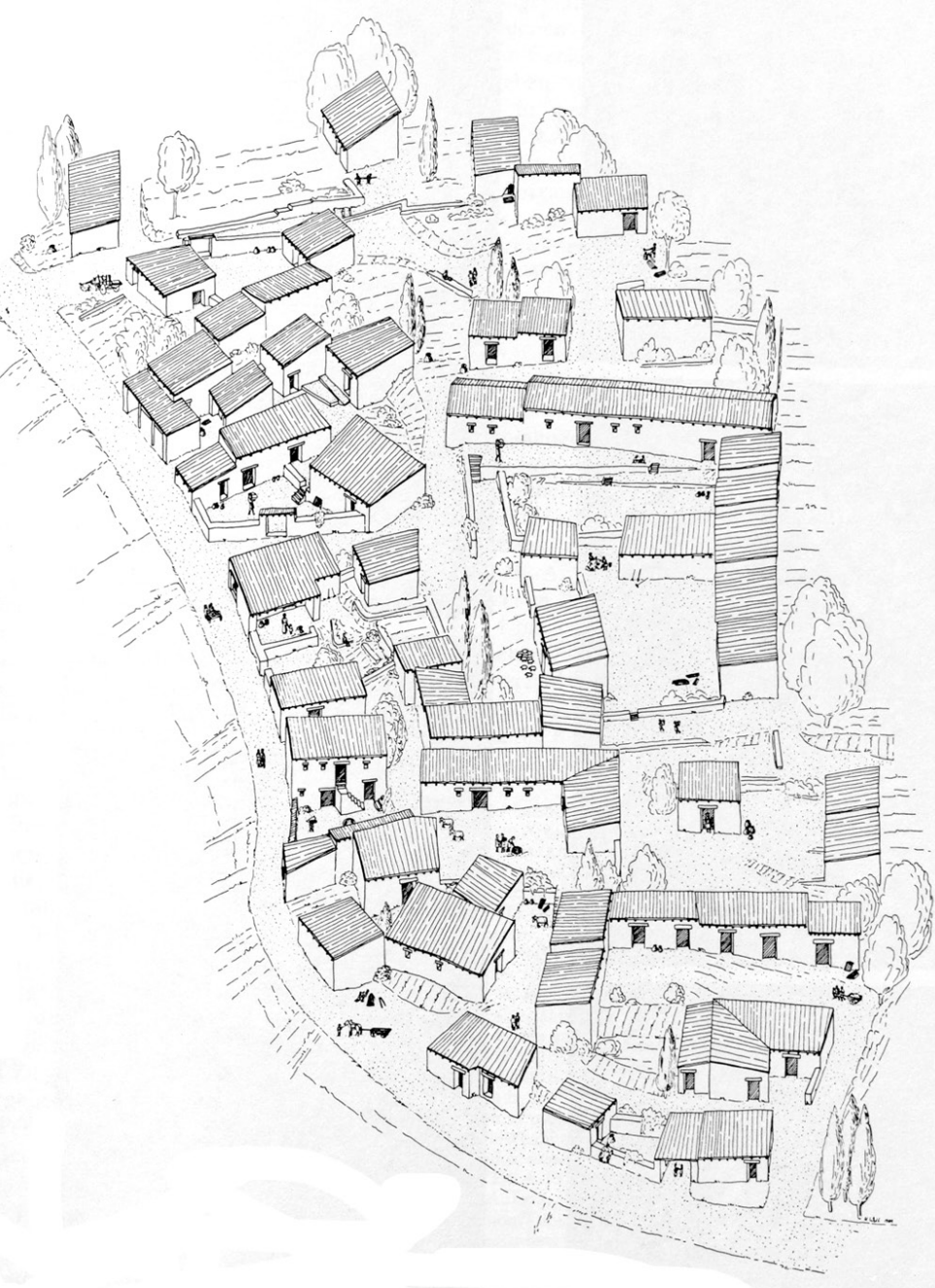

Fig. 11. Reconstruction of Byzantine district in Pergamon, around $14^{\text {th }}$ century. (Source: Rheidt Klaus. "Byzantinische Wohnhäuser des 11. bis 14. Jahrhunderts in Pergamon." In Dumbarton Oaks papers, Dumbarton Oaks Center for Byzantine Studies Washington, DC, 44.1990, 201.) 
It should be noted that the Albanians who chose to emigrate rather than submit to the Turkish rule, considered the exodus not as an escape, but as a transfer of civilizations: they were determined to maintain and preserve their customs and habits.

Typology in architecture has been present since ancient times, it has had great influence on the way buildings have been designed and constructed, and it is present in some of the most famous works of architecture. Although house types in architecture have only been analyzed at length since the nineteenth century, they have played an important role since much earlier. When describing the Fener and Phanariot houses in Istanbul, de Beylié claimed that the protruding levels typical of this type of building were found in Byzantine examples: his theory was based on the Manuscript of Skylitzès. In fact, in his well-known book L'habitation byzantine ${ }^{30}$ he gives some examples of Byzantine house profiles (with projecting rooms) from the above-mentioned manuscript.

In his eloquent paper on the "Balkan house" Marinov ${ }^{31}$ reported that the most important scholars on the Greek vernacular house (such as Anastasios Orlandos and Faidon Koukoules) accepted that the sachnisia of the Northern Greek houses dated back to the Byzantine era and even from antiquity.

Concerning the topic of this paper, the typological analysis suggests that the space inside the Byzantine house, which in the first examples consisted of one or two simple cell-rooms, can be traced to the oldest examples of the Ottoman house. In the Ottoman house this kind of space is no longer only an external space, but serves to connect rooms.

The studies of Klaus Rheidt ${ }^{32}$ on the Byzantine house and that of Eldem on the Ottoman-Turkish house are essential in order to draw a comparison between the two. The comparison of these typological analysis show explicitly the analogies and common features between these housing cultures. Eldem has claimed that the oldest example of the Ottoman-Turkish house, the so-called Sultane Structure, can be traced to the Meriç river valley, near Edirne. According to him the Sultane Structure was a type of building with a raised floor, or fewkani, which had a pillared hall in front of it. A classic example of this type consisted of two or three rooms behind a covered gallery, called hayat. The house had a secondary façade, with pillars, which was the section with the hayat (also known as an outdoor sofa, or hall). The other three sides were closed in by a thick wall and the rooms got light from the back of the hayat. 

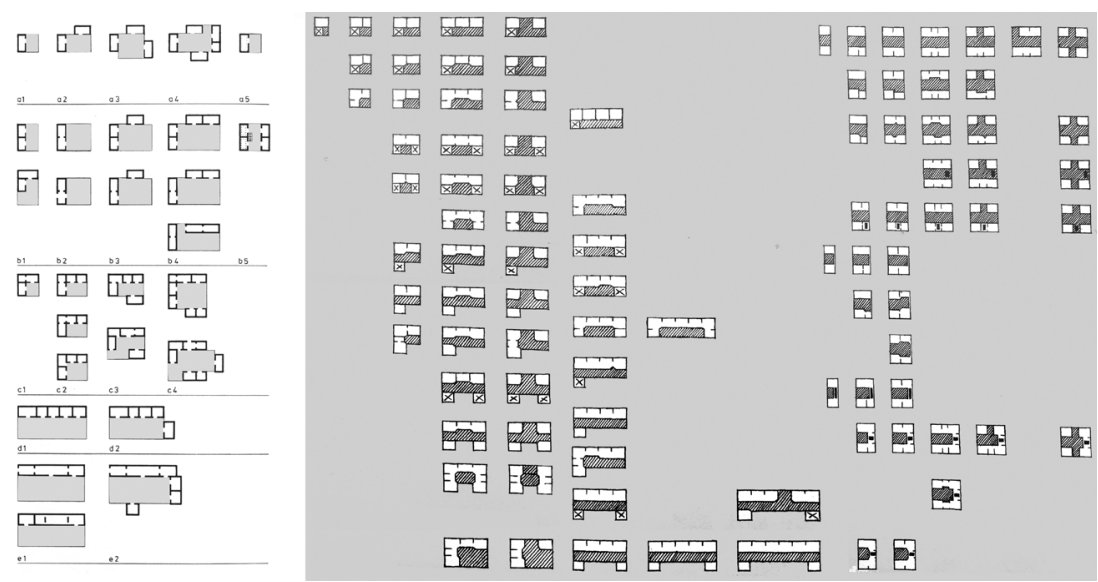

Fig. 12. Comparison between Byzantine house type (from Reidth, 1990) and Ottoman house type (from Eldem, 1984). (Source: Author's picture.)
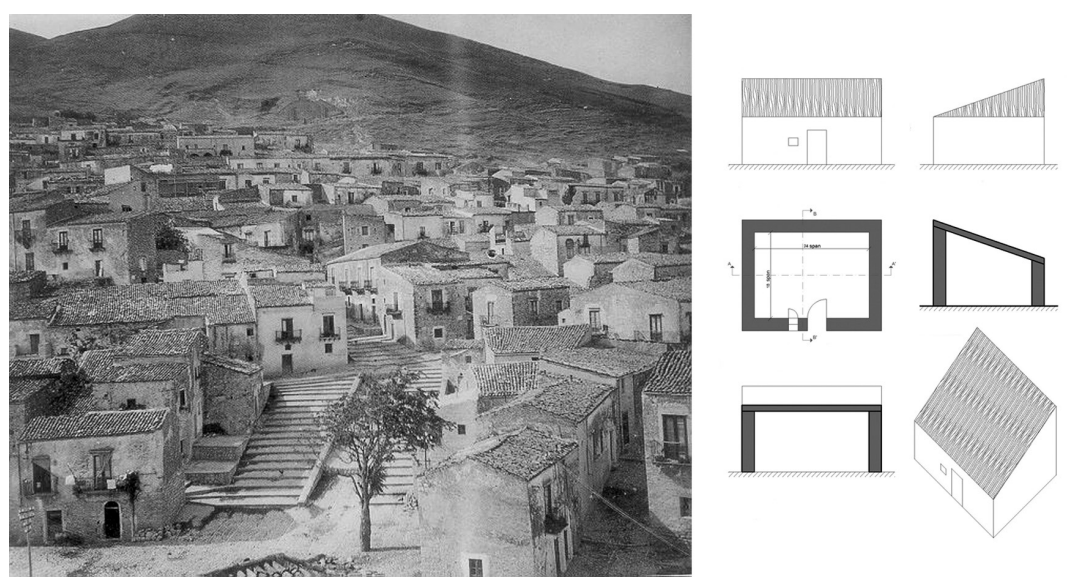

Fig. 13. Left: View of Cavallerizzo di Cerzeto (Kaverici) around 1950s. (Source: URL: http://www. scescipasionatith.it/.) Right: First Arbëreshë housing type, drawings by Francesca Librandi. 
From Rheidt, one can see that the basic examples of the Byzantine house were quite similar to that of "Sultane Structure" described by Eldem. The main elements of the Byzantine house can therefore be summarized as comprised of: a central hall, which opens to separate rooms; the wooden balcony called sahnisin projecting over the street; the main reception room iliakos; the open hall-portico called hayat; and the streets of the town paved with caldirim. Furthermore, in the imperial palaces the reception rooms were multiple and formed a section separated from the private apartments.

\section{CASE STUDIES}

Coming from different geographical area and belonging to different architectural scales these case studies have been selected to demonstrate how some characteristics of the Byzantines houses are even now visible in many places.

Taking into consideration the more urban of these case studies, the Arbëreshë villages of Calabria, one can find that the first rudimentary housing modules kaliva of the Albanian refugees came about after a long use of caves called pagliare, originally made of straw. Successively the houses were made "de calce e de arena", made by mixing chopped branches with red earth, and later using local materials more suitable for housing, such as stones. Thus, the Arbëreshë houses became known as katojo (shed).

The Arbëreshë communities succeeded in reproducing exclusively the town planning dispositions inherited from the Byzantines: a concentric urban development. In these settlements the more relevant concept is called gjitonia. The gjitonia was the smaller portion of the urban fabric, a microstructure consisting of a small square into which alleys (ruhat) converge, surrounded by buildings that have openings towards a larger sheshi or open space ${ }^{33}$. This urban layout will constitute the successive concept of Rione (district). The first forms of urban fabric developed close to main road in these villages, longitudinally expanding and never crossed by primary roads.

The Arbëreshë house type is composed of three macro-elements: the enclosure, the dwelling and the vegetable/botanic garden. The function of the enclosure is to delimit the family environment, and therefore circumscribe the domestic life of the extended family (called "fire" as in the meaning of "hearth" ${ }^{34}$ ). 


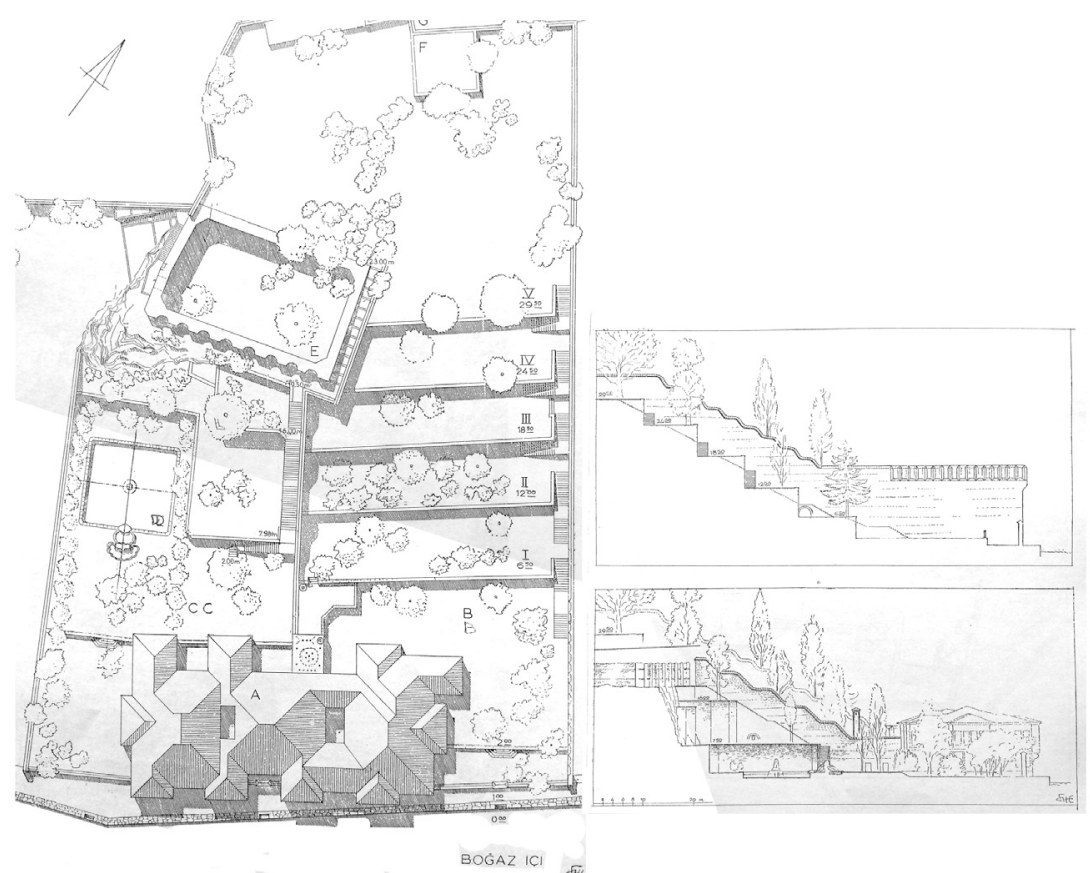

Fig. 14. Preexisting Byzantine reservoir in the garden of Reşid Pasha yalı (mansion) on the Bosphorus, $19^{\text {th }}$ century. (Source: Eldem Sedad Hakkı. Türk Bahçeleri (Turkish Gardens). Istanbul. Kültür Bakanligi yayın, 1976, 80-81.)

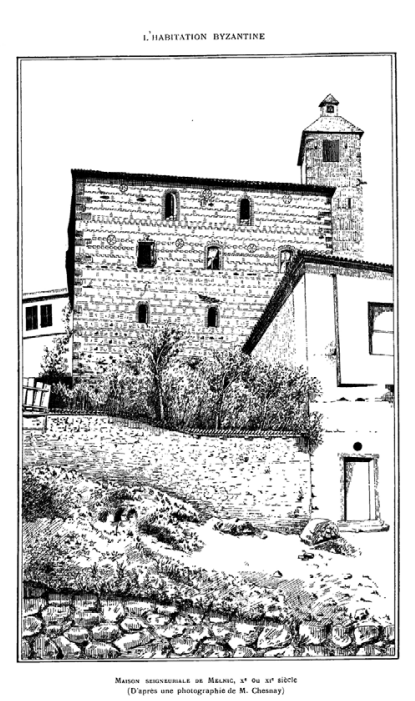

Fig. 15. Byzantine house (kula) in Melnik, $10^{\text {th }}$ $-11^{\text {th }}$ century. (Source: De Beylié Leon. L'habitation byzantine, recherches sur l'architecture civile des Byzantins et son influence en Europe. Grenoble. Éditeur F. Perrin, 1902-1903, 72.)

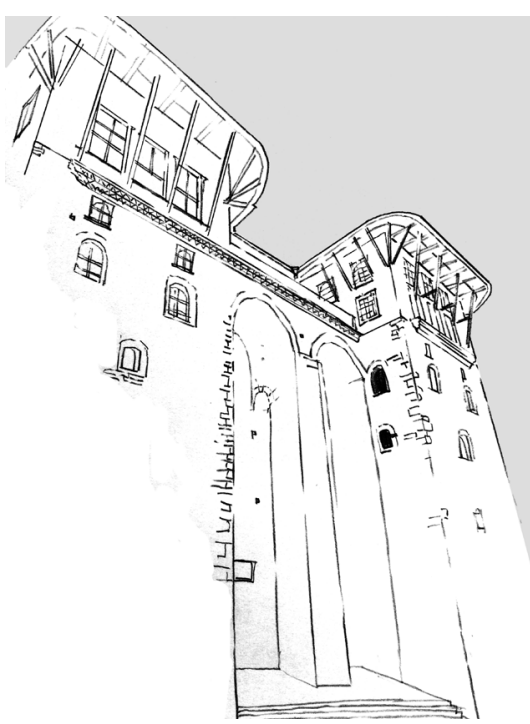

Fig. 16. House in Gjirokastër, early $19^{\text {th }}$ century. (Source: Author's drawing.) 
Also speaking of "etymology of places" we find a remarkable similarity between Albania and southern Italy. For instance, the city of a Gjirokastër and the small city of Castroregio contain in their names the word "kastro/castro" from Latin castrum literally, (castle, fortress). Both were born as protected villages with a concentric urban disposition.

Continuing with the ruins of Mystras, one can see the structure of a Byzantine city. Here it is evident that there is not a typological difference between the house and the palace: thus, the Palace of the Despots in Mystras can be viewed as a large mansion. Later the same correspondence will characterize also the Ottoman urban fabric. Moreover, comparing the plan of the Palace of the Despots with the plan of the Laskaris mansions (also in Mystras) one can notice that houses and palaces were enlarged with new housing units: this kind of compositional procedure was possible thanks to the connective space of these buildings deriving from the ancient Roman triclinium.

The city of Gjirokastër is an extraordinary example of where the Ottoman city meets the byzantine "art de batir". Born in a period of turmoil, the so called City of Stone ${ }^{35}$ was first mentioned in a chronicle on the uprising against the Byzantine Empire in 1336.

Here, the Balkan-Byzantine tower house (kula) finds its perfect union with the Ottoman house. The large stone volumes of the basements and the lower floors of the houses accommodate the cisterns ${ }^{36}$ for recovery and storage of rainwater. Ottoman architecture is often found in those places where the primary urbanization (i.e. the implementation of nature) has Byzantine origins. An extraordinary example of this are the Ottoman gardens ${ }^{37}$ on the Bosphorus, where the Byzantine water reservoirs and supply systems are still to be found in the garden layouts.

The Vicolo Iannelli in Cortona (western Tuscany) is a particular street of the town where the Medieval (or better Byzantine) manner determines the urban layout: a row of houses with a projecting first and second floors located in a small town very close to the so-called Byzantine Corridor ${ }^{38}$ of Central Italy. This was the only passage connecting the two main power centers in Italy (Ravenna and Rome) within the ruins of the dismembered Western Roman Empire between the second half of the sixth century and the demise of the Lombards. 


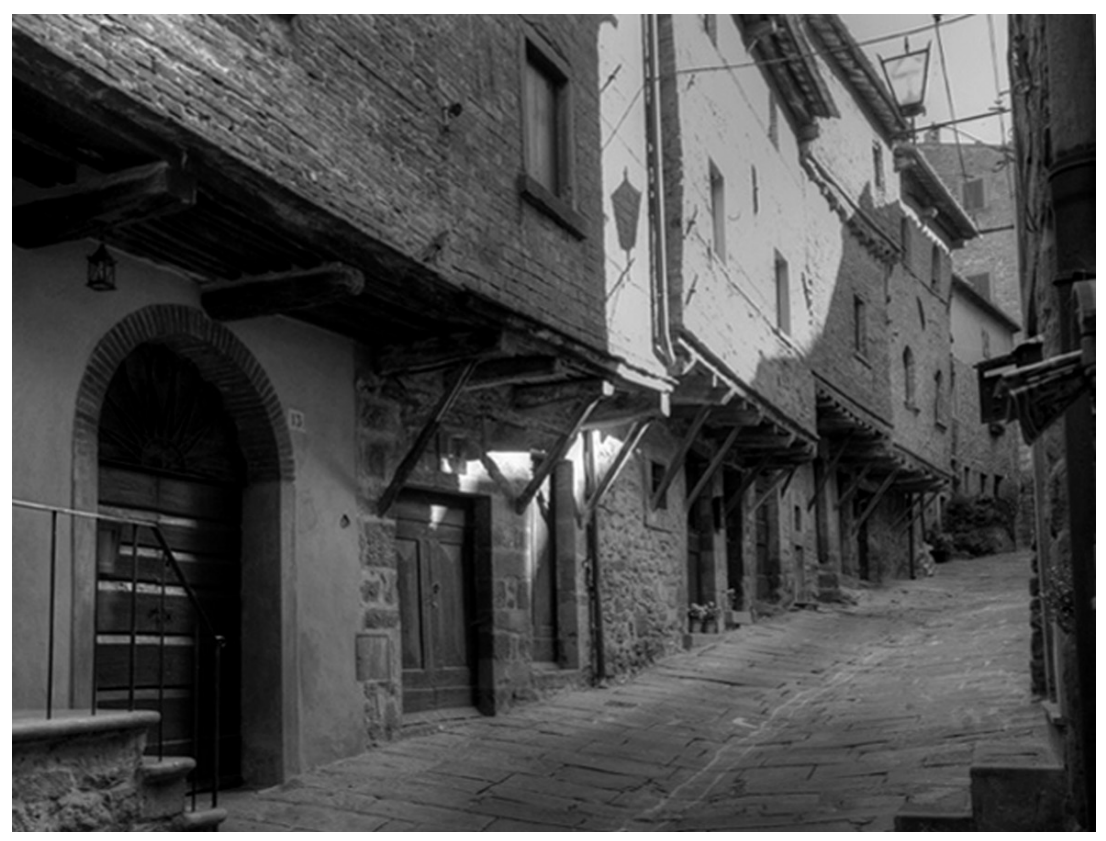

Fig. 17. Vicolo Iannelli in Cortona (Western Tuscany). (Source: Author's photograph.)
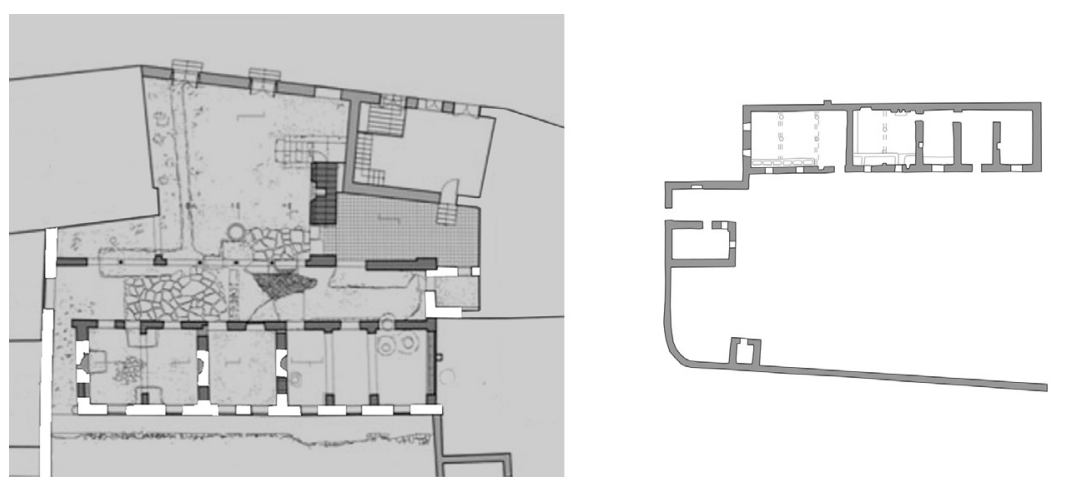

Fig. 18. Comparison between the original structures of the Benizelou's first building, early $16^{\text {th }}$ century (left) and the house in Alişam $11^{\text {th }}-14^{\text {th }}$ century (from Reidht, 1990, right). (Source: Author's drawing.) 
Built at the beginning of the fourteenth century these houses are considered in Italy to belong to Medieval housing architecture but perhaps a closer look at them reveals their Byzantine origins. In fact, from the exterior these small houses and streets bring to mind some Istanbul streets with the echo of Byzantium still visible.

The Benizelou Mansion, located in the Plaka district, just under the Acropolis Hill in Athens, was built on two earlier stone-built structures that were incorporated into the ground floor of the later building. Its original plan is highly similar to the Byzantine typology reported by Reidht. One can observe how the original structures of the Benizelou's first building are reminiscent of the layout of the Byzantine house (in Alişam) documented by Reidht with its rows of rooms and a wall, which determines the earliest concept of fence. These structures, as evidenced by the traces they left in the walls of the ground floor - beam sockets, cupboards, a fireplace - were relatively low tile-roofed houses with a semi-subterranean katoi (shed) and a fireplace on the upper floor. This layout was superimposed by the Ottoman mansion in the seventeenth and early eighteenth century. The Benizelou Mansion is an extraordinary proof of how different cultures have coexisted in the Hellenic core of Athens.

\section{CONCLUSION}

Deroko's intuitions have paved the way for the rediscovery of a common cultural heritage. The Byzantine house as predecessor of the Ottoman house is a multidisciplinary subject that would deserve a new round of studies. Currently, the experience of modern architects in documenting this particular cultural heritage is the essential step toward a contemporary awareness of how we can still learn from the vernacular tradition, in particular the housing tradition of eastern Mediterranean countries.

Working on this paper I have been able to collect examples to demonstrate how the Byzantine housing concept is a living housing culture. For instance the Arbëreshë settlements, an unstudied subject in the Mediterranean context, has been reframed and analyzed here within a broader context. I have demonstrated my primary idea that the Arbëreshë houses tell another story with respect to the Southern Italy housing tradition. The Arbëreshë refugees never faced the Ottoman domination; and the fact that their houses in Italy echoed the Byzantine housing tradition from the time they left Albania is arguably not a coincidence. 
The case studies analyzed here demonstrate the existence of Byzantine elements (in house plans, urban layouts, and the decorative aspect of façades) of civil buildings from a vast geographical area. This study highlights that Byzantine traces in architecture are present also in civil buildings, and not only in religious buildings, as is commonly thought. Lastly, this current study demonstrates that the Byzantine housing culture has survived until today. This building type represents a cultural heritage with transnational meaning and a wide range of characteristics. As such, it should be properly studied from a historical, international, and cross-cultural perspective. This study is a first step in this direction. 

also would like to acknowledge Renata Jadrešin Milić for her invaluable help and support, as well as Atanasio Pizzi and Francesca Librandi for having shared with me the housing concepts of the Arbëreshë culture.

1

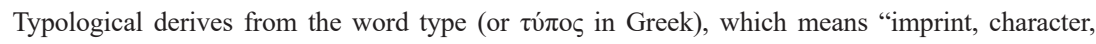
figure, model". Aldo Rossi considered this concept as one of the "principles of architecture". See Aldo Rossi, L'architettura della città (Padova: Marsilio, 1966).

Nikolaos K. Moutsopoulos, "Bref aperçu des agglomerations traditionelles de la Grèce," Storia della città 31/32 (1984): 10-32.

Kaštel Lukšić (Croatia) was built by the aristocratic family Vitturi (probably of Venetian origins) from Trogir, at the end of the fifteenth century. It has the shape of a large fortified Renaissance palace - summer mansion surrounded by the sea in the past and today connected with the mainland. That is the house called 'Byzantine house' in via del Colle in Tivoli. 
Aleksandar Deroko, "Deux genres d'architecture dans un monastère," Revue des études byzantines tome 19 (1961): 382-389.

See Nikos Georgiadis, Mistra (Ninth Edition), (Athens, 2006).

Ibid., 20-21.

Regarding Mount Athos and importance of this site for modern architecture by means of Le Corbusier's experience see: Jelena Bogdanović, "Le Corbusier's testimonial to Byzantine architecture on Mt. Athos," in Institut d'études Byzantines de L'académie Serbe Des Sciences et des Arts, 44/2 (Belgrade, 2015).

See Leon De Beylié, L'habitation byzantine, les anciennes maisons de Constantinople, ed. F. Perrin (Grenoble, 1902-1903).

Karl M. Swoboda, Römische und romanische Paläste, eine architekturgeschichtliche Untersuchung (Wien, Köln, Böhlau, 1969).

Sergio Bettini, Venezia nascita di una città (Milano: Electa, 1988), 90. See also Francesco Collotti, "Il Progetto e l'antico nell'area Altoadraiatica, Il caso dell'Arsenale di Venezia" (PhD Dissertation. Venezia. IUAV, 1990).

Ennio Concina, La città bizantina (Roma-Bari: Editori Laterza, 2003).

Tatiana K. Kirova, "Il problema della casa bizantina," in Felix Ravenna 4 (1971): 263-302.

See Kojić Branislav, "L'habitation seigneuriale d'Avzipacha à Bardovce près de Skoplje," Zbornik zaštite spomenika kulture no. 4-5 (1954): 223-242.

Čipan made all the drawings in Kojić's book. Furthermore, he graduated in 1941 from the Architectural Department of the Faculty of Technical Sciences in Belgrade in the class of prof. Kojić on the topic: "Village Settlement Center". http://marh.mk/борис-чипан-1918-2012/.

Aleksandar Deroko, Srednjevekovni gradovi u Srbiji, Crnoj Gori i Makedoniji (Medieval towns in Serbia, Montenegro and Macedonia) (Belgrade: Prosveta, 1950).

Boris Čipan, "L'ancienne architecture d'immeuble à Ohrid," in Actes du XIIe Congrès international d'études byzantines: Ochride 1016 septembre 1961 (Beograd: Comité yougoslave d'études byzantines, 1963-1964), 151. Available at: http://www.icomos.org/publications/thessalonique1973/ thessalonique1973-17.pdf.

Serena Acciai, Sedad Hakkı Eldem, an Aristocratic Architect and More (Firenze: FUP Firenze University Press, 2018); see also Sibel Bozdogan, Suha Özkan and Engin Yenal, Sedad Eldem: Architect in Turkey (Architects in the Third World) (Singapour, New York NY: Concept Media, 1987).

Sedad Hakkı Eldem, Turk Evi, Osmanli Dönemi = Turkish Houses, Ottoman Period (Istanbul: Turkiye Anit Cevre Turizm Degerlerini Koruma Vakfi, 1984-1987), 3 vol.

Ibid., 25.

He is one of the most important intellectuals engaged in the study of traditional Greek architecture, and professor at the Aristotle University of Thessaloniki.

In fact, Faidon Koukoules stated that the Byzantines called the protruding volume iliakos - a vernacular term - coming from helios/ilios ("sun").

Nikolaos K. Moutsopoulos, "Bref aperçu des agglomerations traditionelles de la Grèce," op. cit., 24.

An example of this net is the Sedad Eldem's correspondence, see: Serena Acciai, "The OttomanTurkish House according to Sedad Hakk1 Eldem, A refined domestic culture suspended between Europe and Asia," ABE Journal [Online], 11 (2017). Available at: http://abe.revues.org/3676. 
The IV CIAM was held onboard ship, the SS Patris II, which sailed from Marseille to Athens. See Gemma Belli, "IV Congrès d'Architecture Moderne: architetti in viaggio verso il Mediterraneo," in Immaginare il Mediterraneo. Architettura, Arti, Forografia, eds. Andrea Maglio, Fabio Mangone, Antonio Pizza (Napoli: artstudiopaparo, 2017).

Aleksandar Deroko, Deux genres d'architecture dans un monastère, op. cit., 384.

See Serena Acciai, 'The Ottoman-Turkish House according to Sedad Hakki Eldem, A refined domestic culture suspended between Europe and Asia'. op. cit.

Thanks to the passion and the meticulous research done by architect Atanasio Pizzi we have been able to reconstruct the history of the Arbëreshë settlements in Calabria, during the fourteenth and fifteenth century. See http://www.scescipasionatith.it/.

The documentary evidence on Arbëreshë housing settlements has been possible thanks to civil engineer and architect Francesca Librandi.

Leon De Beylié, L'habitation byzantine, recherches sur l'architecture civile des Byzantins et son influence en Europe, ed. F. Perrin (Grenoble: 1902-1903).

Tchavdar Marinov, "The "Balkan House": Interpretations and Symbolic Appropriations of the Ottoman-Era VernacularArchitecture in the Balkans," in Entangled Histories of the Balkans (Leiden, The Netherlands: BRILL, 2017). doi: https://doi.org/10.1163/9789004337824_008.

Rheidt (1955) is a German architect and Byzantine scholar. See Klaus Rheidt, "Byzantinische Wohnhäuser des 11. bis 14. Jahrhunderts in Pergamon," in Dumbarton Oaks papers (Dumbarton Oaks Center for Byzantine Studies Washington, DC, 44.1990), 195-204.

In the Arbëreshë culture, the sheshi is the outside section of the house. Its origins referred to the concept of the balcony conceived in an ample meaning. Currently, it also means a small square.

The hearth, "Fire": the unitary fulcrum of the Arbëreshë community is the enlarged family, represented as an assembly placed all around the fireplace. The concept of Gjitonia was born around this "fire": it is a spiritual dwelling that can't stay in a small and precise place. It is also a cultural emblem that preserves the sense of belonging to the Arbëreshë community.

Ismail Kadaré, The Fall of the Stone City (Berat: Onufri, 2008).

Elena Mamani and Kreshnik Merxhani, "Water Cisterns In Historical Houses Gjirokastër," Proceedings of the $2^{\text {nd }} I C A U D$ International Conference in Architecture and Urban Design Epoka University (Tirana, Albania, 08-10 May 2014).

Sedad Hakkı Eldem, Türk Bahçeleri (Turkish Gardens) (Istanbul: Kültür Bakanligi Yayin , 1976).

Giorgio Ravegnani, L'Italia Bizantina (Bologna: Il Mulino, 2016), 86. 
Acciai, Serena. “Divanhane, the receiving room.” Firenze Architettura 2 (2016): 146-151.

Acciai, Serena. "The Ottoman-Turkish House according to Sedad Hakkı Eldem, A refined domestic culture suspended between Europe and Asia.” ABE Journal [Online], 11 (2017).

Acciai, Serena. Sedad Hakk Eldem, an Aristocratic Architect and More. Firenze. FUP Firenze University Press, 2018.

Bettini, S. L'architettura bizantina. Firenze: Barbèra, Alfani \& Venturi, 1937.

Bettini, S. Lo spazio architettonico da Roma a Bisanzio. Bari: Edizioni Dedalo, 1992.

Bettini, Sergio. Venezia nascita di una città. Milano: Electa. 1988

Bogdanović, Jelena. "Le Corbusier's testimonial to Byzantine architecture on Mt. Athos." In ПЕPIBO $\Lambda \mathrm{O} \Sigma$ - Mélanges offerts à Mme Mirjana Živojinović, membre de l'Académie, eds. D. Dželebdžić and B. Miljković, Belgrade: Institute of Byzantine Studies, (2015): 607-623.

Bozdogan, Sibel, Suha Özkan and Engin Yenal. Sedad Eldem: Architect in Turkey (Architects in the Third World). Singapour, New York NY: Concept Media, 1987.

Čipan, Boris. "L'ancienne architecture d'immeuble à Ohrid." Actes du XIIe Congrès international d'études byzantines: Ochride 1016 septembre 1961. Beograd: Comité yougoslave d'études byzantines, 1963-1964. 149-162.

Choisy, Auguste. L'art de bâtir chez les Byzantins. Paris: 1883.

Concina, Ennio. La città bizantina. Roma-Bari: Editori Laterza, 2003.

Ćurčić, Slobodan. Architecture in the Balkans. New Haven, London: Yale University Press, 2010.

De Beylié, Leon. L'habitation byzantine, les anciennes maisons de Constantinople. Edited by F. Perrin. Grenoble: 1902-1903.

De Beylié, Leon. L'habitation byzantine, recherches sur l'architecture civile des Byzantins et son influence en Europe. Edited by F. Perrin. Grenoble: 1902-1903.

Deroko, Aleksandar. Srednjevekovni gradovi u Srbiji, Crnoj Gori i Makedoniji [Medieval towns in Serbia, Montenegro and Macedonia]. Belgrade: Prosveta, 1950.

Deroko, Aleksandar. “Origine de notre ancienne maison urbaine.” In Bulletin De L'académie Serbe des Sciences Tome XIX: Section des Sciences Sociales, (présenté à la séance du 7 ix 1954), 55 56. Belgrade: Srpska akademija nauka i umetnosti, 1957.

Deroko, Aleksandar. “Quelques reflexions sur l'aspect de l'habitation Byzantine.” In International Congress of Byzantine Studies, 10, 1955 Istanbul, X. Milletlerarasi Bizans Tetkikleri Kongresi Tebliğleri $=$ Actes du X. Congrès International d'Études Byzantines, 124-127. Istanbul: 1957.

Deroko, Aleksandar. "Deux genres d'architecture dans un monastère." Revue des études byzantines, 19 (1961): 382-389.

Eldem, Sedad. Hakkı. Türk Bahçeleri [Turkish Gardens]. Istanbul. Kültür Bakanligi yayını, 1976.

Eldem Sedad Hakkı. Türk Evi, Osmanli Dönemi = Turkish Houses, Ottoman Period. Istanbul. Turkiye anit cevre turizm değerlerini koruma vakfi, 1984-1987, 3 vol.

Eldem Sedad Hakk1. Toward a Local Idiom: A Summary History of Contemporary Architecture in Turkey. In Conservation as Cultural Survival, Holod Renata(eds.). Philadelphia, PA. Aga Khan Award for Architecture, 1980.

Georgiadis, Nikos. Mistra. Athens: 2006.

Gurlitt, Cornelius. Die Baukunst Konstantinopels. Berlin: Wasmuth,1907.

Librandi, Vincenzo. Vakarici : Vaccarizzo Albanese : genesi storica di una comunità : famiglie, avvenimenti e luoghi della memoria. Vol. I-II. Cosenza: Amministrazione Comunale, 2006-2009.

Kadaré Ismail. The Fall of the Stone City. Berat: Onufri, 2008. 
Kirova, Tatiana K. "Il problema della casa bizantina.” Felix Ravenna, 4 (1971): 263-302.

Krautheimer, Richard. Tre capitali cristiane topografia e politica. Venice: Edizioni di Comunità, 2002 (first edition 1983).

Kojić, Branislav. "L'habitation seigneuriale d'Avzipacha à Bardovce près de Skoplje." Zbornik zaštite spomenika kulture, no. 4-5 (1954): 223-242.

Mamani, Elena and Kreshnik Merxhani. "Water Cisterns In Historical Houses Gjirokastër." Proceedings of the $2^{\text {nd }}$ ICAUD International Conference in Architecture and Urban Design Epoka University. Tirana, Albania, 08-10 May 2014.

Marinov, Tchavdar. "The "Balkan House": Interpretations and Symbolic Appropriations of the Ottoman-Era VernacularArchitecture in the Balkans." In Entangled Histories of the Balkans. Leiden, The Netherlands: BRILL, 2017.

Moutsopoulos, Nikolaos K. "Bref aperçu des agglomerations traditionelles de la Grèce." Storia della città, Milano 9 (1984): 10-32.

Muller-Weiner,W. Bildlexikon zur Topographie Istanbuls. Byzantion. Tübingen: Wasmuth, 1977.

Rheidt, Klaus. "Byzantinische Wohnhäuser des 11. bis 14. Jahrhunderts in Pergamon." In Dumbarton Oaks papers, 165-204. Washington, DC: Dumbarton Oaks Center for Byzantine Studies, 1990.

Ravegnani,Giorgio. L'Italia Bizantina, Bologna: Il Mulino, 2016.

Rossi, Aldo. L'architettura della città. Padova: Marsilio, 1966.

Rossi, Aldo. "Senza titolo.” I terreni della tipologia, Casabella 509/510 (1985).

Stahl, Paul-Henri. “A. Deroko, Narodno neimarstvo (Architecture folklorique)." L'Homme 12 (1972): 155-156. 